\title{
The effects of exhaust emissions of using hybrid engine in vehicles
}

Adem BICER, Semin KAYA

DOI: $10.30464 /$ jmee.2018.2.3.209

Cite this article as:

Bicer A., Kaya S. The effects of exhaust emissions of using hybrid engine in vehicles. Journal of Mechanical and Energy Engineering, Vol. 2(42), No. 3, 2018, pp. 209-216.

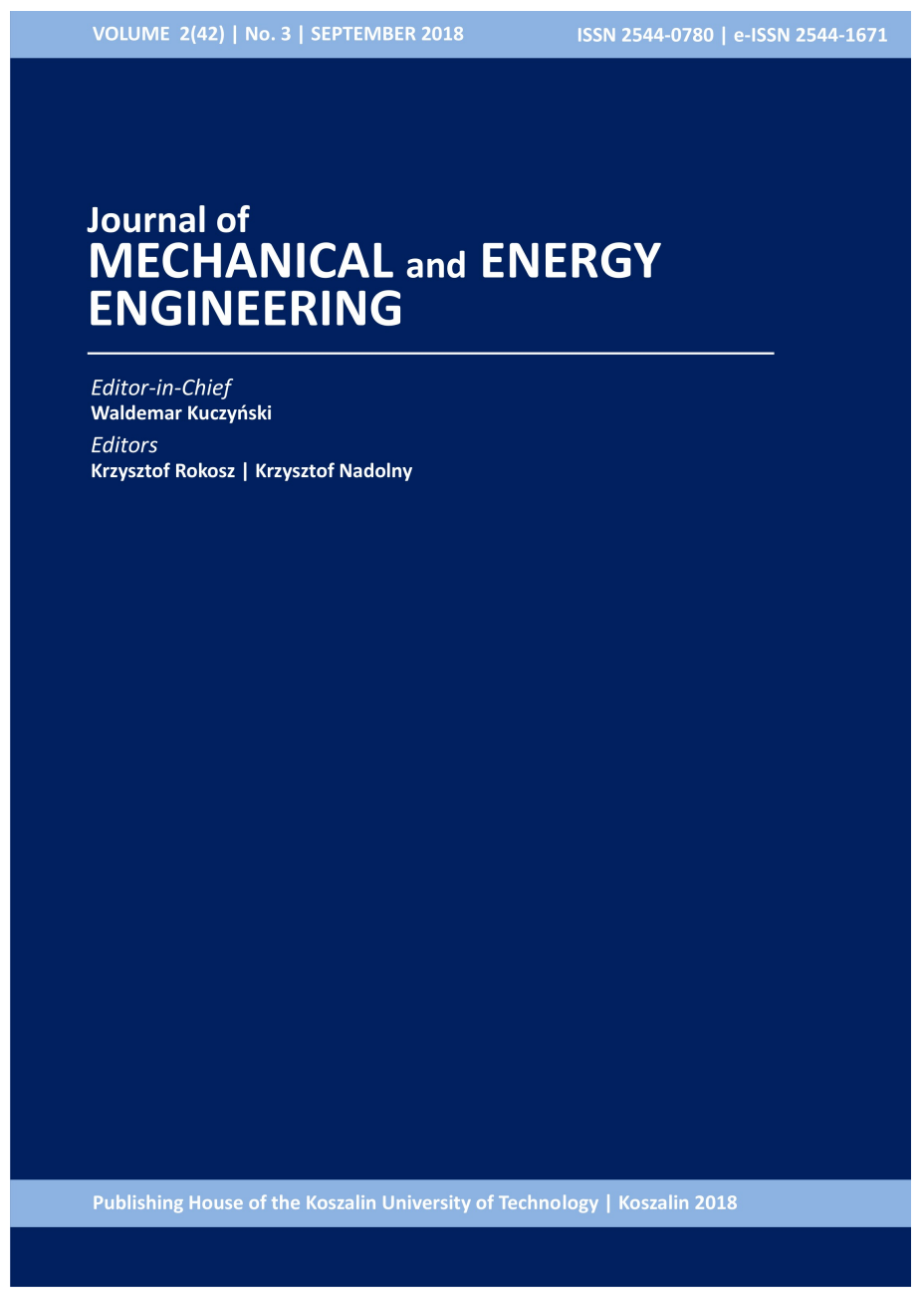

Journal of Mechanical and Energy

Engineering

Website: jmee.tu.koszalin.pl

ISSN (Print): 2544-0780

ISSN (Online): 2544-1671

Volume: 2(42)

Number: 3

Year: 2018

Pages: 209-216

Article Info:

Received 20 July 2018

Accepted 10 September 2018

\section{Open Access}

This article is distributed under the terms of the Creative Commons Attribution 4.0 (CC BY 4.0) International License (http://creativecommons.org/licenses/by/4.0/), which permits unrestricted use, distribution, and reproduction in any medium, provided you give appropriate credit to the original author(s) and the source, provide a link to the Creative Commons license, and indicate if changes were made. 


\title{
THE EFFECTS OF EXHAUST EMISSIONS OF USING HYBRID ENGINE IN VEHICLES
}

\author{
Adem BICER $^{1^{*}}$, Semin KAYA ${ }^{2}$ \\ ${ }^{1 *}$ Institute of Sciences, Department of Mechanical Engineering, Balikesir University, Turkey, \\ e-mail: adem.bicer93@gmail.com \\ ${ }^{2}$ Faculty of Engineering, Department of Mechanical Engineering, Balikesir University, Turkey, \\ e-mail: skaya@balikesir.edu.tr
}

(Received 20 July 2018, Accepted 10 September 2018)

\begin{abstract}
At the beginning of the work on the effects of global warming and climate change in the international area, there are efforts to reduce exhaust emissions. Because fossil fuel is depleting and exhaust emission gases emitted to the atmosphere are rising rapidly, energy efficiency is on the agenda in transportation. Therefore, automotive developers and scientists have undertaken new research in the automotive sector. Hybrid electric vehicle technology is one of the important studies that these researchers continue. In the hybrid electric vehicle technology, the hybrid engine is aimed to give the best results in terms of exhaust emission, fuel consumption and maintenance costs compared to other internal combustion engines, and at the same time the hybrid engine is aimed to perform better than other internal combustion engines. General information about the hybrid electric vehicle technology as one of the new and alternative technologies in these study is provided. In addition, information was given about exhaust emission, emission standards and fuel consumption. Comparisons were made between the hybrid engine and other internal combustion engines.
\end{abstract}

Keywords: hybrid electric vehicle, hybrid drive systems, hybrid engine, exhaust emissions, fuel consumption, emission standards,

\section{INTRODUCTION}

Today, global warming and depletion of fossil fuels are on the agenda. At the top of these problems is the transportation sector. These problems have appeared because of an increase in the amount of fuel used in transportation and an excessive release of pollutant gases and $\mathrm{CO}_{2}$ gas. Therefore, greenhouse gas and global warming that may be dangerous to our world is continuing. In order to solve these problems, alternative fuels and different engine types have been used. One of the alternative engine types is the hybrid engine [1-4].

The hybrid engine includes both an internal combustion engine and an electric engine, so by using the hybrid engine the aim is to have less fuel consumption, a lower release of pollutant gases and $\mathrm{CO}_{2}$ gas, smaller maintenance costs, higher acceleration and higher performance [2, 5-7]. Because of the advantages of the hybrid engine, these, the hybrid engine is better than another vehicle engines (the petrol engine, the diesel engine etc.).

In this article, general information about the hybrid engine was given. Information about the working principle, components, using charge units, types (serial, parallel, and complex), advantages and disadvantages of the hybrid engine were given [2]. Moreover, information about exhaust emission, emission standards and fuel consumption were given, and the hybrid engine was compared with other engine types.

The aim of the study is to examine hybrid motor vehicles, one of the alternative technologies that provide less pollution and improved fuel economy and provide energy efficiency.

\section{HYBRID DRIVE IN VEHICLES}

The first of the studies related to hybrid drive were started that included both the internal combustion engine and the electric engine at the end of the $19^{\text {th }}$ century [8]. 
For the hybrid drive vehicle to move, it needs an internal combustion engine in addition to an electric engine.

A typical hybrid drive consist of a battery, an internal combustion engine, an electric engine, an electric generator, a power split unit, and a power split device that uses a special type of gearbox to smoothly distribute power from the two types of engines, and a generator (Fig. 1) [2].

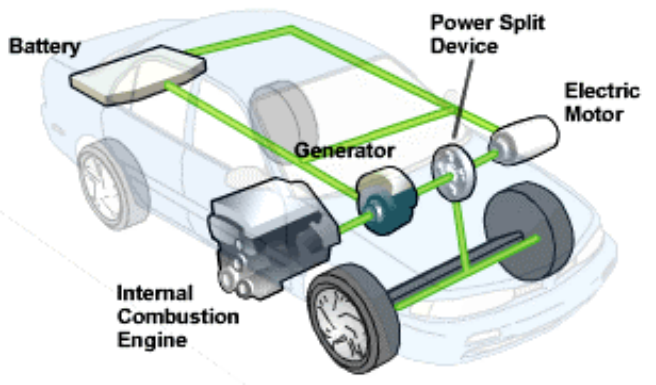

Fig. 1. The components of hybrid engine on vehicle [9]

\subsection{Working principle of the hybrid drive}

When the vehicle starts to move, only the electric engine runs. During this time, the internal combustion engine is off. The electric engine produces high torque at low rotation according to the internal combustion engine, so owing to the electric engine soft start is obtained[2, 8].

In terms of energy, the internal combustion engine is not efficient when driving at low and medium speeds. On the other hand, the electric engine is more efficient in that condition. So at low and medium speeds, the vehicle uses energy stored in the battery to use its electric engines [2,8].

When the vehicle is driven at a constant speed, the internal combustion engine runs. Power produced by the internal combustion engine is used to drive the wheels. At the same time, some of the generated power is collected in the generator. The energy in the generator is either used to charge the batteries, or provides energy directly to the electric motor $[2,8]$.

In the case of accelerating, the energy that is stored in the batteries is used to run the electric engine, and the electric engine is used to drive the wheels together with the internal combustion engine $[2,8]$

During braking and deceleration, the wheels are used as a regenerator and it is utilized from kinetic energy of the vehicle. Normally, this energy that is turned to friction and heat is stored in the battery for being used again at slowing. Moreover, the internal combustion engine cannot run during braking and deceleration $[2,8]$.

During stopping, the internal combustion engine, the electric engine and the generator are off, so that energy conservation is provided $[2,8]$.

\subsection{Types of the hybrid drive}

In this system, according to the connection type of the electric engine with the internal combustion engine are classified as a series hybrid system, a parallel hybrid system and a complex hybrid system $[8,10]$.

\subsubsection{Series hybrid drive system}

In a series hybrid drive system (Fig. 2.), the internal combustion engine drives a generator, which in turn powers the electric engine from the converted electricity of the generator to drive the wheels. The internal combustion engine and the electric engine perform approximately the same amount of work [10-12].

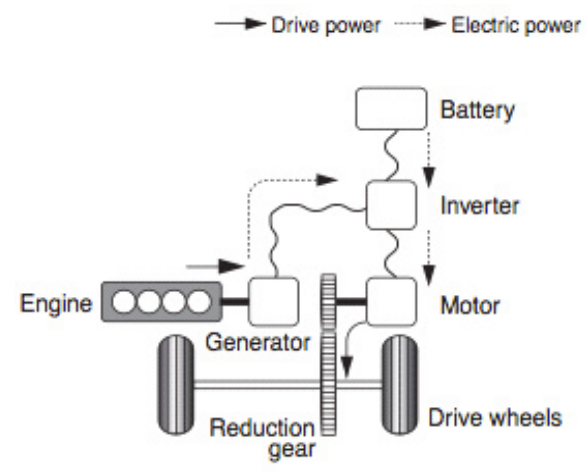

Fig. 2. Series hybrid drive system [11]

\subsubsection{Parallel hybrid drive system}

In this system, the internal combustion engine and the electric engine, which are parallel to each other, drive the wheels. In contrast, in the series hybrid drive system mentioned earlier, only the electric engine would be driving the wheels. The internal combustion engine in a parallel system, however, is the main power source and it is used much more than the electric engine, which is used mainly to provide acceleration. (Fig. 3.) [10-12].

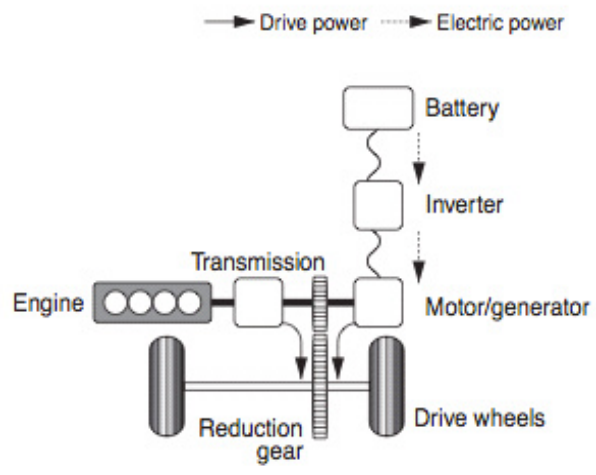

Fig. 3. Parallel hybrid drive system [11] 


\subsubsection{Complex (series/parallel) hybrid drive system}

Lastly, the most efficient system is the complex (series/parallel) hybrid drive system. (Fig. 4.) This system combines both of the previous systems to maximize the benefits of both, which in turn delivers drivers the best fuel efficiency available. In this case, since the electric engine can run on electricity as it is generated, it is used more than the internal combustion engine $[10,11]$.

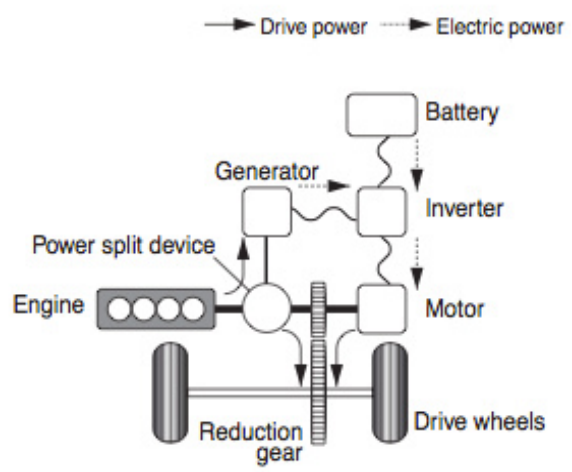

Fig. 4. Complex (series/parallel) hybrid drive system [11]

\section{COMPONENTS OF THE HYBRID ELECTRIC VEHICLES}

As already mentioned, one hybrid electric vehicle consists of a battery, an internal combustion engine, an electric engine, an electric generator, a power split unit, and a power split device. The most important of them are battery and electric engine [2, 10, 13].

\subsection{Electric engine types of using in hybrid electric vehicles}

The electric engine is worked as the driving engine, the alternator and the starter engine. (Fig. 5.) One electric engine with the power of $54 \mathrm{HP}$ generates the maximum $210 \mathrm{Nm}$ torque [8]. In reality, these values can change according to the types of the electric engine. If we examine electric engine types, it is as follows.

The types of the electric engine are DC engine, brushless DC engine, asynchronous engine, synchronous engine, and brushless synchronous DC engine. The most useful of them is the brushless DC engine. Because, according to others, the brushless DC engine is lighter, less volume and it provides high power density, high efficiency and a high moment but its cost is high [13, 14].

As a result, the electric engine provides impressive starting and acceleration performance in almost all driving conditions.

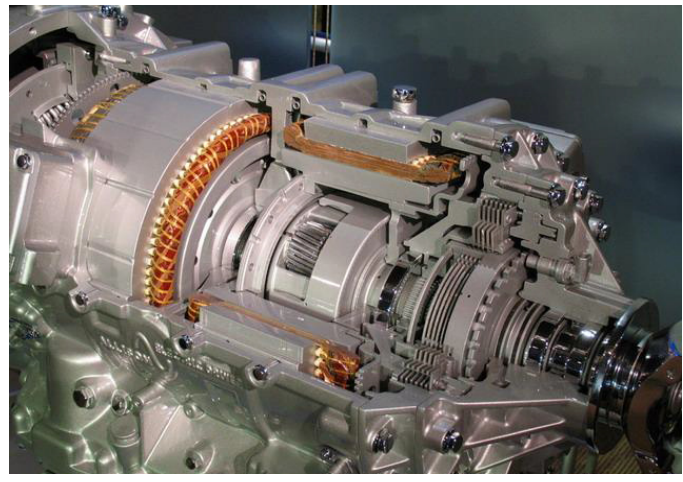

Fig. 5. Electric engine in hybrid electric vehicle [8]

\subsection{Battery types of using in hybrid electric} vehicles

In generally, as the battery in hybrid electric vehicles, Li-ion, NiMH batteries are used. Other than these, also super capacitors as energy storage units. Super capacitors have longer life than battery systems and can store high energy in a short time. But the prices are high. So the best solution for hybrid electric vehicles is Li-ion batteries, cf. the Table 1 [13-15].

In general, the specific power, specific energy of the batteries to be used in hybrid electric vehicles must be high, long lasting and low cost [8, 15]. Hence, according to Table 1 , in terms of all of rates Li-ion battery is the best selection.

Tab. 1. Comparison of the energy storage systems [14]

\begin{tabular}{cccc}
\hline Comparison & $\begin{array}{c}\text { Super } \\
\text { capacitor }\end{array}$ & NiMH & Li-ion \\
\hline Voltage & $125 \mathrm{VDC}$ & $288 \mathrm{VDC}$ & $324 \mathrm{VDC}$ \\
\hline $\begin{array}{c}\text { Max. } \\
\text { Current }\end{array}$ & $750 \mathrm{~A}$ & $\begin{array}{c}190 \mathrm{~A} \\
(10 \mathrm{~s})\end{array}$ & $\begin{array}{c}270 \mathrm{~A} \\
(15 \mathrm{~s})\end{array}$ \\
\hline $\begin{array}{c}\text { Specific } \\
\text { Power }\end{array}$ & $1,7 \mathrm{Wh} / \mathrm{kg}$ & $40 \mathrm{Wh} / \mathrm{kg}$ & $90 \mathrm{Wh} / \mathrm{kg}$ \\
\hline $\begin{array}{c}\text { HEV } \\
\text { Specific } \\
\text { Power }\end{array}$ & $1 \mathrm{Wh} / \mathrm{kg}$ & $4 \mathrm{Wh} / \mathrm{kg}$ & $18 \mathrm{Wh} / \mathrm{kg}$ \\
\hline $\begin{array}{c}\text { Power } \\
\text { Capacity }\end{array}$ & $100 \mathrm{Wh}$ & $2400 \mathrm{Wh}$ & $14,6 \mathrm{kWh}$ \\
\hline $\begin{array}{c}\text { HEV Power } \\
\text { Capacity }\end{array}$ & $70 \mathrm{Wh}$ & $240 \mathrm{Wh}$ & $2920 \mathrm{Wh}$ \\
\hline \begin{tabular}{l} 
Weight \\
\hline
\end{tabular} & $55 \mathrm{~kg}$ & $88 \mathrm{~kg}$ & $160 \mathrm{~kg}$ \\
\hline
\end{tabular}

Batteries to be used in hybrid electric vehicles must be selected according to the vehicle's energy management system and vehicle configuration (Fig. 6.) [8]. 


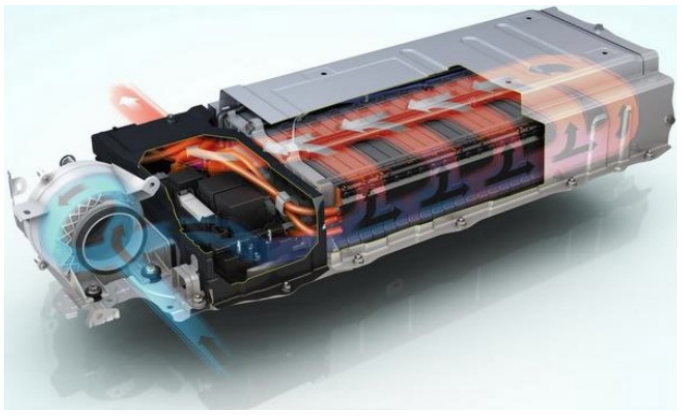

Fig. 6. Battery of the hybrid electric vehicle [16]

\section{ADVANTAGES AND DISADVANTAGES OF THE HYBRID ELECTRIC VEHICLES}

The hybrid engine in vehicles has many advantages over internal the combustion engine. But they have disadvantages since the hybrid engines are improved constantly [8].

Below are listed the main advantages of hybrid electric vehicles.

1. The exhaust emission is lower, so the environment is less polluted [8].

2. The hybrid electric vehicles are more fuelefficient [8].

3. Vehicle balance is better given that the engine is in the center and on the sides [8].

4. Owing to the electric engine the vehicle is started smoothly and silently. Moreover, the electric engine produces high torque at low rotation compared to the internal combustion engine [2,8].

Below are listed the main disadvantages of the hybrid electric vehicles.

1. It is more expensive than an internal combustion engine [8].

2. Although these types of vehicles do not directly pollute air, there is an increase in the amount of sulfur dioxide and carbon dioxide emitted from the thermal power plants due to fossil fuels, since the energy required to recharge them is derived from thermal power plants. In short, air pollution is continuing indirectly [8].

3. Development work of the hybrid electric vehicle is continuing as electric engine's range is short, the battery life is short and the battery is heavy [8].

\section{PERFORMANCE, EFFICIENCY AND FUEL CONSUMPTION OF THE HYBRID ELECTRIC VEHICLES}

Nowadays, the maximum power of most vehicles is $100 \mathrm{~kW}$. The average power used in highway and urban traffic is around $7.5 \mathrm{~kW}$. At this light load, the engine efficiency is as low as $20 \%$, so that today the fuel economy of the hybrid electric vehicles is increased two or three times and the fuel economy of the vehicle is significantly increased [8].

As shown in Table 2, the fuel consumption of the hybrid electric vehicle and conventional internal combustion engine vehicle in the same engine peak power and in the same engine maximum torque are compared. The comparison resulted in a gain of 50 percent in fuel consumption.

Tab. 2. Comparison of fuel consumption of HEV and Conventional ICE Vehicle [17]

\begin{tabular}{|c|c|c|}
\hline Parameters & $\begin{array}{l}\text { Conventional } \\
\text { ICE Vehicle }\end{array}$ & $\begin{array}{l}\text { Hybrid Electric } \\
\text { Vehicle (HEV) }\end{array}$ \\
\hline $\begin{array}{c}\text { Engine Peak } \\
\text { Power }\end{array}$ & $38.2 \mathrm{~kW}$ & $38.2 \mathrm{~kW}$ \\
\hline $\begin{array}{l}\text { Engine Max. } \\
\text { Torque Nm. / } \\
\text { rpm. }\end{array}$ & $\begin{array}{c}85 \mathrm{Nm} . / 2500 \\
\mathrm{rpm} .\end{array}$ & $\begin{array}{c}85 \mathrm{Nm} . / 2500 \\
\mathrm{rpm} .\end{array}$ \\
\hline $\begin{array}{c}\text { HEV Battery } \\
\text { Pack } 4 \times 12 \mathrm{~V} \\
\text { Lead Acid type }\end{array}$ & & $150 \mathrm{Ah}$ \\
\hline Passenger Mass & $150 \mathrm{~kg}$ & $150 \mathrm{~kg}$ \\
\hline $\begin{array}{c}\text { Curb weight of } \\
\text { vehicle }\end{array}$ & $1050 \mathrm{~kg}$ & $1250 \mathrm{~kg}$ \\
\hline Total Test Mass & $1200 \mathrm{~kg}$ & $1400 \mathrm{~kg}$ \\
\hline \multirow{4}{*}{$\begin{array}{c}\text { Fuel } \\
\text { Consumption } \\
\text { Liters/100Km. }\end{array}$} & 4.65 & 2.29 \\
\hline & 4.83 & 2.62 \\
\hline & 5.05 & 2.19 \\
\hline & 5.12 & 1.97 \\
\hline
\end{tabular}

Hybrid electric vehicles have very low fuel consumption levels. Hybrid electric vehicles running on M 85 (85\% methanol and 15\% gasoline) have 90\% smaller fuel consumption than conventional vehicles. Today, in the tests of hybrid electric vehicles produced, it is reduced to $3 \mathrm{lt}$. fuel consumption at 100 $\mathrm{km}$. However, the maximum fuel economy is provided by reducing the weight of hybrid electric vehicles, so that exhaust emissions of the hybrid electric vehicles will also be reduced [8].

\section{EXHAUST EMISSION IN THE VEHICLES}

The gases that are appear with the combustion of fuel - air mixtures in internal combustion engines and emitted to atmosphere are called exhaust gases. The release of these pollutant gases are called exhaust emissions $[18,19]$.

The parameters required for the combustion process to occur are as follows: the fuel - air mixture must be in a certain amount and the fuel must be at the ignition point temperature.

As shown in Figure 7, $\mathrm{HC}$ (hydrocarbon), and $\mathrm{S}$ (sulphur) as fuel and $\mathrm{O}_{2}$ (oxygen), $\mathrm{N}_{2}$ (nitrogen), $\mathrm{H}_{2} \mathrm{O}$ (hydrogen dioxide) as air enter the reaction. The gases $\mathrm{N}_{2}$ (nitrogen), $\mathrm{O}_{2}$ (oxygen), $\mathrm{H}_{2} \mathrm{O}$ (hydrogen dioxide), $\mathrm{CO}_{2}$ (carbon dioxide), $\mathrm{CO}$ (carbon monoxide), $\mathrm{NO}_{\mathrm{X}}$ 
(nitrogen oxides), $\mathrm{SO}_{2}$ (sulphur dioxide), and $\mathrm{HC}$ (hydrocarbon) are released as post-reaction exhaust gas $[18,19]$.

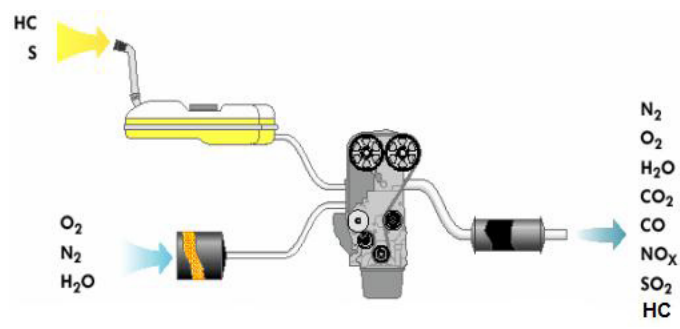

Fig. 7. The exhaust gases as result of the fuel-air mixture [18]

These exhaust gases are caused due to the fact that the combustion is not fully realized, fuel - air mixture is rich mixture or poor mixture. Moreover, spark advances, compression ratio, air / fuel ratio, excess air factor, fuel quality, flame velocity, engine friction, combustion chamber design, vehicle design, vehicle aerodynamics affects exhaust emission [18-20].

\subsection{Exhaust emission gases that are emitted due to the vehicles}

As previously described, the resulting exhaust gases occurred because of the reaction of the fuel air mixture. These are the most important exhaust gases.

\section{$\mathrm{CO}_{2}$ (Carbon dioxide)}

$\mathrm{CO}_{2}$ (Carbon Dioxide) is the least harmful gas among the emission gases resulting from combustion. Carbon dioxides are converted to oxygen through photosynthesis by plants. Furthermore, carbon dioxide causes greenhouse effect in the atmosphere $[18,19]$.

\section{CO (Carbon monoxide)}

The main reason for the presence of $\mathrm{CO}$ among combustion products; fuel is reacted by 1 oxygen instead of 2 oxygen, so that $\mathrm{CO}$ gas occurs. The $\mathrm{CO}$ gas is a poisonous gas $[18,19]$.

\section{HC (Hydrocarbon)}

HC (hydrocarbon) occurs when the fuel does not burn completely and the fuel evaporates (at fuel tank or during fuel filling) $[18,19]$.

\section{$\mathrm{NO}_{\mathrm{x}}$ (Nitrogen oxides)}

At high temperatures reached by combustion, due to the fact that oxygen combines with nitrogen in air, nitrogen oxides occur. Two important parameters affecting $\mathrm{NO}_{\mathrm{X}}$ formation are combustion chamber temperature and air / fuel ratio. The chemical reaction rates and the amount of oxygen are also important here $[18,19]$.

In addition, especially in diesel engines, $\mathrm{SO}_{2}$, particulate matter and soot occur [18, 19].

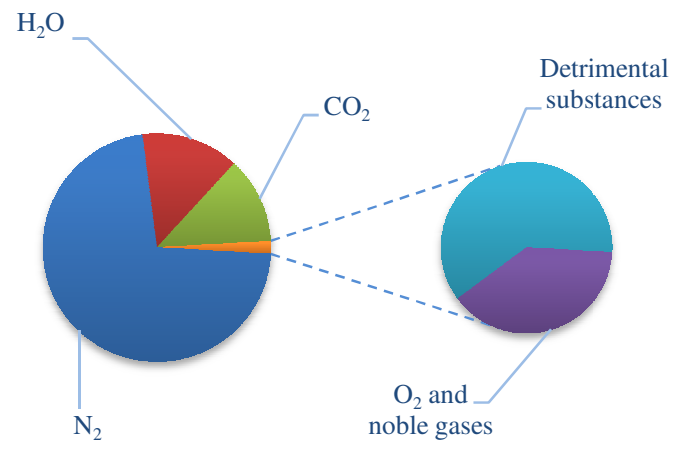

Fig. 8. Exhaust emission gases in gasoline engines [21]

As shown in Figure 8, the $\mathrm{N}_{2}$ is $72,1 \%$, the $\mathrm{H}_{2} \mathrm{O}$ is $13.8 \%$, the $\mathrm{CO}_{2}$ is $12.3 \%, \mathrm{O}_{2}$ and noble gases are 0.7 $\%$ and detrimental substances are $1.1 \%$ in gasoline engines. The detrimental substances include $\mathrm{CO}, \mathrm{HC}$, $\mathrm{PM}$ (particulate matter), $\mathrm{NO}_{\mathrm{X}} \cdot$ [21].

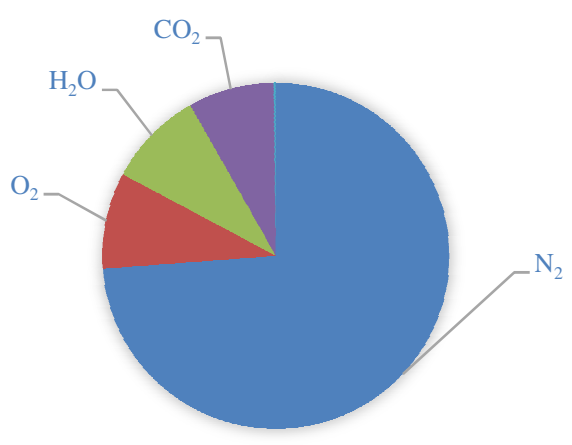

Fig. 9. Exhaust Emission Gases in Diesel Engines [21]

As shown in Figure $9, \mathrm{~N}_{2}$ is $73.8 \%, \mathrm{H}_{2} \mathrm{O}$ is $9 \%$, the $\mathrm{O}_{2}$ is $9 \%$, the $\mathrm{CO}_{2}$ is $8 \%$, and detrimental substances are $0.2 \%$ in the diesel engines. The detrimental substances include $\mathrm{NO}_{\mathrm{X}}, \mathrm{CO}, \mathrm{HC}, \mathrm{PM}$ (particulate matter), $\mathrm{SO}_{2}$ [21].

\section{EUROPEAN EMISSION STANDARDS}

Nowadays, the increase in the number of vehicles causes environmental pollution. To prevent this environmental pollution, exhaust emission values have been standardized in vehicles. Since many countries have ratified the Kyoto Protocol aimed at reducing emissions, automakers and scientists work to reduce air pollution, so that it has been decided that each vehicle will give exhaust gas to the surrounding area in a certain standard. These standards are classified according to years and exhaust emission values are gradually being reduced [22].

The first regulations on emissions in the world began in California in 1968, and the first limitation began in 1972 with the Regulation ECE R 15.00 and 
Regulation EEC $72 / 220$ in the European Union countries [22].

The engines produced before conforming to a specific emission standard before the standards introduced by the EU are called Non euro (pre-euro standards) engines. After the limitations, Euro I was passed between 1992-1993, Euro II between 1995-1996, Euro III in 2000, Euro IV in 2005, Euro V in 2009 and Euro VI in 2014 [18].

The following in Table 3, Table 4, Table 5 and Table 6 show the exhaust emission values according to Euro standards, vehicle types and fuel types. When the tables were examined, exhaust emission values were reduced as the years progressed.

Nowadays, engines are constantly being developed to comply with emission limits. Hybrid engines, one of the alternative energy technologies in the future "Zero Emission" target, are on the agenda [22].

Tab. 3. European emission standards for passenger cars $(\mathrm{g} / \mathrm{km})$ [22]

\begin{tabular}{|c|c|c|c|c|c|c|c|}
\hline Tier & Date & $\mathrm{CO}$ & THC & NMHC & $\mathrm{NO}_{\mathrm{X}}$ & $\begin{array}{l}\mathrm{HC}+ \\
\mathrm{NO}_{\mathrm{X}}\end{array}$ & $\mathrm{PM}$ \\
\hline \multicolumn{8}{|c|}{ Diesel } \\
\hline Euro I & July 1992 & $\begin{array}{c}2.72 \\
(3.16)\end{array}$ & & & & $\begin{array}{c}0.97 \\
(1.13)\end{array}$ & $\begin{array}{c}0.14 \\
(0.18)\end{array}$ \\
\hline $\begin{array}{c}\text { Euro } \\
\text { II }\end{array}$ & $\begin{array}{c}\text { January } \\
1996\end{array}$ & 1.0 & & & & 0.7 & 0.08 \\
\hline $\begin{array}{c}\text { Euro } \\
\text { III }\end{array}$ & $\begin{array}{c}\text { January } \\
2000\end{array}$ & 0.64 & & & 0.50 & 0.56 & 0.05 \\
\hline $\begin{array}{c}\text { Euro } \\
\text { IV }\end{array}$ & $\begin{array}{c}\text { January } \\
2005\end{array}$ & 0.50 & & & 0.25 & 0.30 & 0.025 \\
\hline $\begin{array}{c}\text { Euro } \\
\mathrm{V}\end{array}$ & $\begin{array}{c}\text { September } \\
2009\end{array}$ & 0.50 & & & 0.180 & 0.230 & 0.005 \\
\hline $\begin{array}{c}\text { Euro } \\
\text { VI }\end{array}$ & $\begin{array}{c}\text { September } \\
2014\end{array}$ & 0.50 & & & 0.080 & 0.170 & 0.005 \\
\hline \multicolumn{8}{|c|}{ Gasoline } \\
\hline Euro I & July 1992 & $\begin{array}{c}2.72 \\
(3.16)\end{array}$ & & & & $\begin{array}{c}0.97 \\
(1.13)\end{array}$ & \\
\hline $\begin{array}{c}\text { Euro } \\
\text { II }\end{array}$ & $\begin{array}{c}\text { January } \\
1996\end{array}$ & 2.2 & & & & 0.50 & \\
\hline $\begin{array}{c}\text { Euro } \\
\text { III }\end{array}$ & $\begin{array}{c}\text { January } \\
2000\end{array}$ & 2.3 & 0.20 & & 0.15 & & \\
\hline $\begin{array}{l}\text { Euro } \\
\text { IV }\end{array}$ & $\begin{array}{c}\text { January } \\
2005\end{array}$ & 1.0 & 0.10 & & 0.08 & & \\
\hline $\begin{array}{c}\text { Euro } \\
\mathrm{V}\end{array}$ & $\begin{array}{c}\text { September } \\
2009\end{array}$ & 1.0 & 0.10 & 0.068 & 0.060 & & 0.005 \\
\hline $\begin{array}{c}\text { Euro } \\
\text { VI }\end{array}$ & $\begin{array}{c}\text { September } \\
2014\end{array}$ & 1.0 & 0.10 & 0.068 & 0.060 & & 0.005 \\
\hline
\end{tabular}

Tab. 4. European emission standards for light commercial vehicles $(1305 \mathrm{~kg}-1760 \mathrm{~kg})(\mathrm{g} / \mathrm{km})$ [22]

\begin{tabular}{|c|c|c|c|c|c|c|c|}
\hline Tier & Date & $\mathrm{CO}$ & THC & NMHC & $\mathrm{NO}_{\mathrm{X}}$ & $\begin{array}{l}\mathrm{HC}+ \\
\mathrm{NO}_{\mathrm{X}}\end{array}$ & PM \\
\hline \multicolumn{8}{|c|}{ Diesel } \\
\hline Euro I & $\begin{array}{c}\text { October } \\
1994\end{array}$ & 5.17 & & & & 1.4 & 0.19 \\
\hline Euro II & $\begin{array}{c}\text { January } \\
1998\end{array}$ & 1.25 & & & & 1.0 & 0.12 \\
\hline Euro III & $\begin{array}{c}\text { January } \\
2001\end{array}$ & 0.80 & & & 0.65 & 0.72 & 0.07 \\
\hline $\begin{array}{c}\text { Euro } \\
\text { IV }\end{array}$ & $\begin{array}{c}\text { January } \\
2006\end{array}$ & 0.63 & & & 0.33 & 0.39 & 0.04 \\
\hline Euro V & $\begin{array}{c}\text { September } \\
2010\end{array}$ & 0.63 & & & 0.235 & 0.295 & 0.005 \\
\hline $\begin{array}{c}\text { Euro } \\
\text { VI }\end{array}$ & $\begin{array}{c}\text { September } \\
2015\end{array}$ & 0.63 & & & 0.105 & 0.195 & 0.005 \\
\hline \multicolumn{8}{|c|}{ Gasoline } \\
\hline Euro I & $\begin{array}{c}\text { October } \\
1994\end{array}$ & 5.17 & & & & 1.4 & \\
\hline Euro II & $\begin{array}{c}\text { January } \\
1998\end{array}$ & 4.0 & & & & 0.6 & \\
\hline Euro III & $\begin{array}{c}\text { January } \\
2001\end{array}$ & 4.17 & 0.25 & & 0.18 & & \\
\hline $\begin{array}{l}\text { Euro } \\
\text { IV }\end{array}$ & $\begin{array}{c}\text { January } \\
2006\end{array}$ & 1.81 & 0.13 & & 0.10 & & \\
\hline Euro V & $\begin{array}{c}\text { September } \\
2010\end{array}$ & 1.81 & 0.13 & 0.090 & 0.075 & & 0.005 \\
\hline $\begin{array}{c}\text { Euro } \\
\text { VI }\end{array}$ & $\begin{array}{c}\text { September } \\
2015\end{array}$ & 1.81 & 0.13 & 0.090 & 0.075 & & 0.005 \\
\hline
\end{tabular}

Tab. 5. European emission standards for light commercial vehicles $(1760 \mathrm{~kg}-3500 \mathrm{~kg})(\mathrm{g} / \mathrm{km})[22]$

\begin{tabular}{|c|c|c|c|c|c|c|c|}
\hline Tier & Date & $\mathrm{CO}$ & THC & NMHC & $\mathrm{NO}_{\mathrm{X}}$ & $\mathrm{HC}+\mathrm{NO}_{\mathrm{X}}$ & PM \\
\hline \multicolumn{8}{|c|}{ Diesel } \\
\hline Euro I & $\begin{array}{c}\text { October } \\
1994 \\
\end{array}$ & 6.9 & & & & 1.7 & 0.25 \\
\hline Euro II & $\begin{array}{c}\text { January } \\
1998 \\
\end{array}$ & 1.5 & & & & 1.2 & 0.17 \\
\hline Euro III & $\begin{array}{c}\text { January } \\
2001\end{array}$ & 0.95 & & & 0.78 & 0.86 & 0.10 \\
\hline Euro IV & $\begin{array}{c}\text { January } \\
2006\end{array}$ & 0.74 & & & 0.39 & 0.46 & 0.06 \\
\hline Euro V & $\begin{array}{c}\text { September } \\
2010\end{array}$ & 0.74 & & & 0.28 & 0.35 & 0.005 \\
\hline Euro VI & $\begin{array}{c}\text { September } \\
2015\end{array}$ & 0.74 & & & 0.125 & 0.215 & 0.005 \\
\hline \multicolumn{8}{|c|}{ Gasoline } \\
\hline Euro I & $\begin{array}{c}\text { October } \\
1994\end{array}$ & 6.9 & & & & 1.7 & \\
\hline Euro II & $\begin{array}{c}\text { January } \\
1998 \\
\end{array}$ & 5.0 & & & & 0.7 & \\
\hline Euro III & $\begin{array}{c}\text { January } \\
2001\end{array}$ & 5.22 & 0.29 & & 0.21 & & \\
\hline Euro IV & $\begin{array}{c}\text { January } \\
2006\end{array}$ & 2.27 & 0.16 & & 0.11 & & \\
\hline Euro V & $\begin{array}{c}\text { September } \\
2010\end{array}$ & 2.27 & 0.16 & 0.108 & 0.082 & & 0.005 \\
\hline Euro VI & $\begin{array}{c}\text { September } \\
2015\end{array}$ & 2.27 & 0.16 & 0.108 & 0.082 & & 0.005 \\
\hline
\end{tabular}


Tab. 6. European emission standards for heavy commercial vehicles $(\mathrm{g} / \mathrm{kWh})[22]$

\begin{tabular}{cccccc}
\hline & Date & $\mathrm{CO}$ & $\mathrm{HC}$ & $\mathrm{NO}_{\mathrm{x}}$ & $\mathrm{PM}$ \\
\hline Euro I & $\begin{array}{c}1992<85 \\
\mathrm{~kW}\end{array}$ & 4.5 & 1.1 & 8.0 & 0.612 \\
\cline { 2 - 6 } & $\begin{array}{c}1992>85 \\
\mathrm{~kW}\end{array}$ & 4.5 & 1.1 & 8.0 & 0.36 \\
\hline Euro II & $\begin{array}{c}\text { October } \\
1996\end{array}$ & 4.0 & 1.1 & 7.0 & 0.25 \\
\cline { 2 - 6 } & $\begin{array}{c}\text { October } \\
1998\end{array}$ & 4.0 & 1.1 & 7.0 & 0.15 \\
\hline Euro III & $\begin{array}{c}\text { October } \\
1999\end{array}$ & 1.0 & 0.25 & 2.0 & 0.02 \\
\cline { 2 - 6 } & $\begin{array}{c}\text { October } \\
2000\end{array}$ & 2.1 & 0.66 & 5.0 & 0.10 \\
\hline Euro IV & $\begin{array}{c}\text { October } \\
2005\end{array}$ & 1.5 & 0.46 & 3.5 & 0.02 \\
\hline Euro V & $\begin{array}{c}\text { October } \\
2008\end{array}$ & 1.5 & 0.46 & 2.0 & 0.02 \\
\hline Euro VI & $\begin{array}{c}\text { January } \\
2013\end{array}$ & 1.5 & 0.13 & 0.5 & 0.01 \\
\hline
\end{tabular}

\section{INTERPRETATION OF EXHAUST EMISSION VALUES IN HYBRID ENGINE VEHICLES}

Nowadays, air pollution is one of the most important reasons of environmental problems. One of the reasons for this air pollution is also due to vehicles. Emissions from internal combustion engines are being reduced by measures taken by some environmental standards and regulations. The combustion of fossil fuels in internal combustion engines results in the formation of pollutants. These pollutants are dispersed in the atmosphere and react with the effect of sunlight cause the formation of ozone and greenhouse gases. Among the gases causing global warming are methane and chlorofluorocarbon, especially carbon dioxide [2, 23-25].

As shown in Table 7, gasoline, diesel and hybrid electric vehicles are compared in terms of exhaust emissions [2].

As shown in Table 7, the amount of $\mathrm{CO}$ generated by the combustion of fuel in gasoline internal combustion engines (ICE) is considerably higher than in diesel internal combustion engines (ICE) and hybrid electric vehicle (HEV). In addition, gasoline internal combustion engines (ICE) have the highest exhaust emission values. It is seen that the $\mathrm{NO}_{\mathrm{X}}$ value is higher in diesel engines. Hybrid electric vehicles (HEV) do not have all zero emission values, but they have very low emissions compared to diesel internal combustion engines (ICE) and gasoline internal combustion engines (ICE) [2].

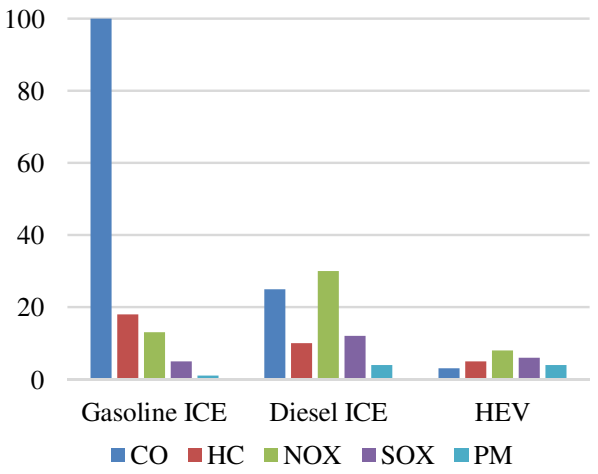

Fig. 10. Comparison of exhaust emission values in percentage according to engine types [2]

In Table 7 the exhaust emission values of a hybrid bus and a conventional bus are compared [2].

Tab. 7. Comparison of exhaust emission values of hybrid bus and conventional bus [2]

\begin{tabular}{ccc}
\hline Emissions $(\mathrm{g} / \mathrm{km})$ & Hybrid Bus & Conventional Bus \\
\hline $\mathrm{HC}$ & 0.433 & 3.622 \\
\hline $\mathrm{CO}$ & 3.466 & 20.566 \\
\hline $\mathrm{NO}_{\mathrm{x}}$ & 6.66 & 25.472 \\
\hline $\mathrm{PM}$ & 0.333 & 3.259 \\
\hline
\end{tabular}

In Table 8, the exhaust emission values of a hybrid diesel vehicle and a conventional diesel vehicle are compared [8]

Tab. 8. Comparison of exhaust emission values of hybrid diesel vehicle and conventional diesel vehicle [8]

\begin{tabular}{cccc}
\hline Emissions $(\mathrm{g} / \mathrm{km})$ & $\mathrm{NO}_{\mathrm{X}}$ & $\mathrm{CO}$ & $\mathrm{HC}$ \\
\hline $\begin{array}{c}\text { Conventional } \\
\text { Diesel Vehicle }\end{array}$ & 0.9 & 0.9 & 0.18 \\
\hline $\begin{array}{c}\text { Hybrid Diesel } \\
\text { Vehicle }\end{array}$ & 0.22 & 0.4 & 0.1 \\
\hline
\end{tabular}

As shown in Table 7 and Table 8, hybrid electric vehicles have lower exhaust emission values than other internal combustion engine vehicles.

\section{CONCLUSIONS}

The development of alternative fuels, improvements in internal combustion engine technology and vehicles with alternative drive systems are on the agenda in order to improve energy efficiency in land transport, which is an important part of the transportation sector.

In European countries, North America and Japan, the amount of fuel used in transportation has begun to be reduced and renewable energy sources instead of fossil fuels used in transportation have begun to be used. However, it has become a necessity to make 
improvements in vehicles in those countries that have agreed to comply with various regulations in order to reduce emissions of fossil fuels.

Nowadays, R \& D activities are made to comply with these standards in vehicles. One of these R \& D activities is hybrid electric vehicle technology. With this technology, "Zero Emission" is targeted in the future, so that this work is increasing day by day in the hybrid vehicle sector.

\section{References}

1. Uçarol, H., et al. (2009). Hybrid and Electric Vehicles are A Alternative for Energy Efficiency in Transportation. In: 3th Symposium on Energy Efficiency and Quality, Kocaeli, TURKEY, 21-22 May, pp. 170174

2. Erbas, S. (2013). The Importance of The Use of New Technologies for Sustainable Public Transport: CostBenefit Analysis of Hybrid Electric Vehicle Use, Publishing House of Bahçeşehir University, Istanbul. (in Turkish)

3. Guner, C. (2013). Comparison Analysis of Plug-in Hybrid Electric Vehicle and Extended Range Electric Vehicle Concepts, Publishing House of Istanbul Technical University, Istanbul. (in Turkish)

4. Fukuo, K., Fujimura, A., Saito, M., Tsunoda, K., Takiguchi, S. (2001). Development of the Ultra-LowFuel-Consumption Hybrid Car-INSIGHT. JSAE review, Vol. 22, pp. 95-103.

5. Mroszczok, J., Schulz, B., Wilsch, K., Frenzer, G., Kasper, S., Seide, G. (2017). Cellulose Aerogel Fibres for Thermal Encapsulation of Diesel Hybrid Engines for Fuel Savings in Cars. Materials Today: Proceedings, Vol. 4, pp. 244-248.

6. Orecchini, F., Santiangeli, A., Zuccari, F., Ortenzi, F., Genovese, A., Spazzafumo, G., Nardone, L. (2018). Energy Consumption of a Last Generation Full Hybrid Vehicle Compared with a Conventional Vehicle in Real Drive Conditions. Energy Procedia, Vol. 148, pp.289296.

7. Daniela, T., De Bellis, V., Enrica, M. (2018). Development of an On-Line Energy Management Strategy for Hybrid Electric Vehicle. Energy Procedia, Vol. 148, pp. 106-113.

8. Anonymous. (2004). Motor Vehicles Technology, Alternative Fuel Motors. Republic of Turkey Ministry of National Education, Ankara.

9. https://www.fueleconomy.gov/feg/hybridtech.shtml (access 13.03.2018).

10. Timucin, B. (2016). Modelling of the Drive System and Design of Powertrain at Hybrid Electric Vehicles, Publishing House of Yildiz Technical University, Istanbul. (in Turkish)

11. http://blog.wellesleytoyota.com/blog/bid/328878/HowYour-Toyota-Hybrid-Engine-Works (access 02.04.2018).

12. Butler, K. L., Ehsani, M., Kamath, P. (1999). A MatlabBased Modeling and Simulation Package for Electric and Hybrid Electric Vehicle Design. IEEE Transactions on vehicular technology, Vol. 48, No. 6, pp. 1770-1778.

13. Cimen, M. A. (2010). Permanent Magnet Synchronous Traction Motor Control by Using a Simulator for Electric and Series Hybrid Electric Vehicles, Publishing House of Istanbul Technical University, Istanbul. (in Turkish)

14. Özelgin, İ., Yıldırım, M. (2008). Evolution of Hybrid Vehicle Components. In: ELECO 6th International Conference on Electrical and Electronics Engineering ELECO`2008, Bursa, TURKEY, 26-30 November.
15. Aras, U. T. (2009). Computer Aided Performance Analysis of Battery Systems of Hybrid Electrical Vehicles, Publishing House of Kocaeli University, Kocaeli. (in Turkish)

16. https://s1.cdn.autoevolution.com/images/news/toyotawants-all-hybrid-car-batteries-recollected-92005_1.jpg (access 02.04.2018).

17. Gupte, S. (2014). Experimental Analysis and Feasibility Study of 1400 CC Diesel Engine Car Converted into Hybrid Electric Vehicle by Using BLDC Hub Motors. Energy Procedia, Vol. 54, pp. 177-184.

18. Anonymous. (2011). Motor Vehicles Technology, Exhaust Emission Control, 525MT0300. Republic of Turkey Ministry of National Education, Ankara.

19. Kelen, F. (2014). Effects of Motor Vehicle Emissions on Human Health and Environment. Yuzuncu Yil University Journal of The Institute of Natural \& Applied Sciences, Vol. 19, No. 1-2, pp. 80-87.

20. Topgul, T., Yucesu, H. S., Okur, M. (2005).The Experimental Investigation of the Effects of Operating Parameters on Exhaust Emissions on a Spark Ignition Engine. Journal of Polytechnic, Vol. 8, No. 1, pp. 43-47.

21. https://www.ngk.de/tr/ayrintilariyla-teknoloji/lambdasensoerleri/egzoz-gazi-ile-ilgili-temel-bilgiler/egzozgazlari-ve-zararli-maddeler/ (access 03.06.2018).

22. http://wowturkey.com/forum/viewtopic.php?p=6266476 (access 05.06.2018).

23. Kapustin, A., Rakov, V. (2017). Methodology to Evaluate the Impact of Hybrid Cars Engine Type on their Economic Efficiency and Environmental Safety. Transportation Research Procedia, Vol. 20, pp. 247-253.

24. Tribioli, L., Bella, G. (2018). Reduction of Particulate Emissions in Diesel Hybrid Electric Vehicles with a PMP-Based Control Strategy. Energy Procedia, Vol. 148, pp. 994-1001.

25. Erbeyler, S. A. (2007). Optimization of Nitrogen Oxide (NOx) Emissions of a Diesel Engine in a Hybrid Electrical Light Commercial Vehicle, Publishing House of Istanbul Technical University, Istanbul. (in Turkish)

\section{Biographical notes}

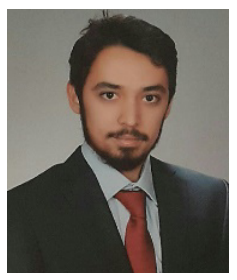

Adem BíçER studied department of mechanical engineering in 2011-2015 at Balikesir University. He is a postgraduate student of Balikesir University the Department of Mechanical Engineering in Turkey. Erasmus+ student at the Faculty of Mechanical Engineering at Koszalin University of the Technology (Poland) in spring season of 2017/2018 academic year. He is interested in hybrid electric vehicles.

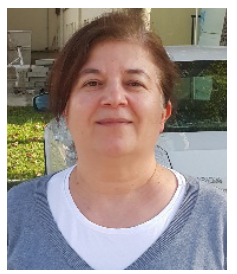

Semin KAYA was born in 1963 in Balikesir (Turkey). She completed department of mechanical engineering as bachelor degree at Uludag University in 1985 and the Department of Mechanical Engineering as the master degree at the Yildiz Technical University in 1987 and at the Department of Mechanical Engineering as the doctorate degree at the Yildiz Technical University in 1997. Since then, she has been working as an assistant professor at the Balikesir University, the Faculty of Engineering at the Department of Mechanical Engineering in Turkey. 